\title{
Peptide Structure Modifications: Effect of Radical Species Generated by Controlled Gamma Ray Irradiation Approach
}

\author{
Renata de Freitas Fischer Vieira, ${ }^{a, \#}$ Daniela Teves Nardi, ${ }^{a}$ Nanci Nascimento, ${ }^{b}$ \\ José César Rosa, ${ }^{c}$ and Clovis Ryuichi Nakaie*,a \\ ${ }^{a}$ Department of Biophysics, Paulista Medical School, Federal University of Sao Paulo; Rua Três de Maio, 100, Sao \\ Paulo 04044020, Brazil: ${ }^{b}$ Nuclear and Energy Research Institute (IPEN), University of Sao Paulo (USP); Av. Lineu \\ Prestes, 2242, Cidade Universitária, Sao Paulo 05508-000, Brazil: and ${ }^{c}$ Protein Chemistry Center and Department \\ of Molecular and Cell Biology, Ribeirao Preto Medical School, University of Sao Paulo (USP); Av. Bandeirantes, \\ 3900-Monte Alegre, Ribeirao Preto 14049-900, Brazil. $\quad$ Received December 4, 2012; accepted January 16, 2013
}

The present work aimed at evaluating the radiolysis effect upon a set of peptides, most of them involved in physiological functions. To generate reactive radical species, a $\mathrm{Co}^{60}$ source (up to $15 \mathrm{kGy}$ ) was used for controlled gamma irradiation of some peptide solutions including derivatives attaching the stable free radical Toac (2,2,6,6-tetramethypiperidine-1-oxyl-4-amino-4-carboxylic acid). Regardless of the peptide sequence, a nonlinear and progressive degradation of a total of nine peptides was detected. The results were interpreted in the light of the half-life dose $\left(D_{1 / 2}\right)$ parameter which represents the dose necessary for $50 \%$ peptide structure degradation. The vasoactive angiotensin II (AngII)'s analogue Ang-(1-7) showed greater stability towards gamma ray radiation than bradykinin $(\mathrm{BK})$, Toac ${ }^{0}-\mathrm{BK}$, Pro ${ }^{4}-\mathrm{BK}\left(D_{1 / 2}\right.$ around 4 and $2 \mathrm{kGy}$, respectively) which decreased to about $0.5-1.0 \mathrm{kGy}$ in the case of acetyl- $\alpha$-melanocyte-stimulating hormone (Ac$\alpha$-MSH) and substance P (SP). In terms of peptide structural modifications, the data acquired from different analytical methods suggested a Phe to Tyr (or its ortho and/or meta isomers) transformation as a consequence of the hydroxyl moiety insertion. Noteworthy, this effect seemed to be position-dependent as only Phe located at or near the C-terminal portion seemed to display this transformation. In contrast, Met is comparatively more easily oxidized, thus allowing to conclude that gamma irradiation may induce a complex position and/ or sequence-dependent effect on peptides. As previously applied for BK, some irradiated peptides were submitted to their by-products purification, indeed a complementary target of the present approach for development of uncommon analogues for further structure-function investigation.

Key words gamma radiation; peptide; mass spectrometry; $\alpha$-melanocyte-stimulating hormone; bradykinin; substance P

The oxidation by free radicals of several macromolecules, mainly affecting protein structures is known to govern several processes within cells, and is implicated in some illness such as cancer, diabetes, Alzheimer's and Parkinson's diseases. ${ }^{1-3)}$ Usually radical species are generated by cleavage bonds or by electron transfer reactions inducing fragmentation, crosslinking or aggregation processes of macromolecules and their fragments. Reactive oxygen radicals are produced in the radiolysis of water but the mechanism and products generated by their actions still remain unclear. This fact is suggested by the complexity of factors that come into play along the interaction between reactive species and the macromolecule. Besides the type and intensity of active radicals, the structure and conformation of the compound, the solvent system and its accessibility, etc., are certainly involved in this process. ${ }^{4-10)}$

Different approaches have been witnessed in the literatures for better investigating this issue and also targeting the development of new compounds with potentials for inhibiting or neutralizing these reactive radicals when they seem to be involved in the induction of different types of human diseases. In this context and following with previous efforts, ${ }^{11,12}$ ) the present report intended to more broadly examine the effect of reactive species generated in solution by gamma ray irradiation- $\mathrm{Co}^{60}$ as the source and in up to $15 \mathrm{kGy}$ controlled dose range-upon the structure and physicochemical features of a

\footnotetext{
The authors declare no conflict of interest.
}

${ }^{\#}$ Equal contribution with corresponding author. total of nine peptide sequences, most of them involved in crucial roles in the human physiology.

The first evaluated set of peptides was related to the important renin-angiotensin and kallikrein-kinin systems (RAS and KKS, respectively). Amongst the former system, ${ }^{13-15)}$ the selected peptides were: the tetradecapeptide (TDP) (DRVYIHPFHLLVYS) and the vasoactive AngII (DRVYIHPF) analogue Ang-(1-7). In the case of the second system, ${ }^{16,17)}$ the hipotensive bradykinin (BK) (RPPGFSPFR) and its Pro $^{4}$-BK derivative were examined.

Following with previous studies initiated with AngII and $\mathrm{BK},{ }^{11,12)}$ these two peptides were now examined under complementary approaches by coupling in their structures, the amino acid-type probe Toac, introduced earlier in the chemistry of peptides. ${ }^{18,19)}$ Thus, Toac ${ }^{1}$-AngII, Toac ${ }^{0}$-BK and Toac ${ }^{3}$-BK paramagnetically labeled derivatives, earlier evaluated in terms of structure-function relationships, ${ }^{20-22)}$ were tested towards their molecular stability under strong electromagnetic radiation procedure. The reason for this option lied on the fact that as Toac is a stable free radical, it would be affected by the submission approach to strong gamma ray irradiation. In regard to the Toac probe, a large amount of works have been progressively appeared in the literature, not only for peptide studies $^{23-27)}$ but also for alternative application in the peptidepolymer or polymer fields. ${ }^{28-31)} \mathrm{A}$ review report detailing the potentials of this paramagnetic and fluorescent quencher spin label was recently published. ${ }^{32}$

In complement to this class of peptides, other physiologi- 
cally active molecules such as the $\alpha$-melanocyte-stimulating hormone $(\alpha-\mathrm{MSH})$ (Ac-SYSMEHFRWGKPV-amide) ${ }^{33,34)}$ and substance P (SP) (RPKPQQFFGLM-amide) $)^{35-37)}$ were also investigated. In this two cases and also of the $\mathrm{Pro}^{4}-\mathrm{BK}$ analogue, after the gamma irradiation step, the main generated by-product derivatives were purified by semi-preparative HPLC and further characterized through different experimental techniques including analytical HPLC, LC/electrospray ionization (ESI)-MS, amino acid analysis and mainly by daughter ion scanning by collision induced dissociation (CID-MS/MS) sequencing procedure. ${ }^{38)}$ In addition to this objective related to the identification of structure modifications occurred for each peptide sequence, the observed gamma ray dose-dependent degradation process of all peptides was also monitored and interpreted in terms of the herein introduced $D_{1 / 2}$ parameter, i.e., the gamma radiation dose responsible for modification of $50 \%$ of the native peptide under consideration.

\section{MATERIALS AND METHODS}

Materials The tert-butyloxycarbonyl (Boc) and 9-fluorenylmethyloxycarbonyl (Fmoc) amino acids were purchased from Bachem (Torrance, CA, U.S.A.). Solvents and reagents were from Aldrich or Sigma (St. Louis, MO, U.S.A.). Prior to their use, $N, N^{\prime}$-dimethylformamide (DMF) was distilled over $\mathrm{P}_{2} \mathrm{O}_{5}$ under reduced pressure. All solvents and chemicals met the standards established by the American Chemical Society.

Methods. Peptide Synthesis and Purification Peptides were synthesized manually by the solid phase peptide synthesis (SPPS) methodology $y^{39-41)}$ using the $t$-Boc strategy. $t$-Boc amino acids couplings were usually performed with $N, N^{\prime}$-diisopropylcarbodiimide (DIC) and 1-hydroxybenzotriazole (HOBt) in dichloromethane (DCM)/DMF or $20 \%$ dimethylsulfoxide/ $N$-methylpiperidine (DMSO/NMP) and recoupled, when necessary, with $N$-[(1H-benzotriazol1-yl)-(dimethylaminomethylene)]- $N$-methylmethanaminium hexafluorophosphate $N$-oxide (HBTU)/diisopropylethylamine (DIPEA)/HOBt acylating agents. In the particular case of Toac-bearing peptides, the synthesis procedure used a combined $t$-Boc and Fmoc strategies as earlier described. ${ }^{19,20)}$ The analogues produced by gamma irradiation experiments were purified through Waters Delta 600 preparative HPLC (semipreparative octadecyl $\left(\mathrm{C}_{18}\right)$ column) (Vydac, Hesperia, CA, U.S.A.). In this step, solvents $A$ and $B$ were aqueous $0.02 \mathrm{M}$ ammonium acetate $(\mathrm{pH} 5)$ and $60 \%$ acetonitrile $(\mathrm{ACN})$ in solvent $A$, respectively (linear gradient of $30-70 \% \mathrm{~B}$ for $2 \mathrm{~h}$, flow rate of $10 \mathrm{~mL} / \mathrm{min}$ at $220 \mathrm{~nm}$ ). The analytical HPLC analyses of peptides were performed in a Waters Alliance 2695 analytical HPLC system (Waters, Milford, U.S.A.) and a 2489 UV/ Visible detector. The samples were analyzed on analytical $\mathrm{C}_{18}$ column, using the following solvent systems: solvent $\mathrm{A}$ $\left(\mathrm{H}_{2} \mathrm{O}\right.$ containing $0.1 \%$ trifluoroacetic acid (TFA)); and solvent $\mathrm{B}(60 \% \mathrm{ACN}$ in solvent A). A linear gradient of $5-95 \% \mathrm{~B}$ in $30 \mathrm{~min}$ was employed at a flow rate of $1.5 \mathrm{~mL} / \mathrm{min}$ and detection at $220 \mathrm{~nm}$. HPLC injections were evaluated in duplicate for each sample with similar results.

Peptide Irradiation Peptide solutions were prepared in Eppendorf tubes with Milli-Q water at neutral $\mathrm{pH}$ to a final dilution of $1 \mathrm{mg} / \mathrm{mL}$. $0.01 \mathrm{M}$ solutions of $\mathrm{NaOH}$ or $\mathrm{HCl}$ were used to adjust the $\mathrm{pH}$ to 7.0. These solutions were exposed to controlled doses of 0.3 to $15 \mathrm{kGy}$ gamma radiation in
Gammacell 220 irradiator (Atomic Energy of Canada Ltd., Ottawa, Canada) in the presence of atmospheric oxygen, at room temperature and at a $3.32 \mathrm{kGy} / \mathrm{h}$ constant dose rate at the Nuclear and Energy Research Institute in Sao Paulo University, Brazil. These experiments were carried out in duplicate.

Amino Acid Analysis Peptide composition was monitored using amino acid analysis performed on a Biochrom 20 Plus amino acid analyzer (Pharmacia LKB Biochrom Ltd., Cambridge, England) equipped with an analytical cation-exchange column. The peptides were hydrolyzed with $6 \mathrm{M} \mathrm{HCl}$ in sealed tubes under nitrogen atmosphere at $110^{\circ} \mathrm{C}$ for $72 \mathrm{~h}$. The samples were concentrated under high vacuum conditions, suspended in $0.2 \mathrm{M}$ sodium citrate buffer, adjusted to $\mathrm{pH} 2.2$ and automatically injected into the analyzer.

Mass Spectrometry The liquid chromatography with electrospray ionization mass spectrometry (LC/ESI-MS) experiments were performed on a system consisting of a separation module Waters Alliance model e2695 and a 2489 UV/ Visible detector, both from Waters Systems (Milford, U.S.A.). These equipments were coupled to a mass detector Waters model 3100 and were controlled by a workstation ThinkCentre. The samples were automatically injected onto a Waters narrow bore Nova-Pak column $\mathrm{C}_{18}(2.1 \times 150 \mathrm{~mm}, 60 \AA$ pore size, $3.5 \mu \mathrm{m}$ particle size). The elution was carried out with solvents $\mathrm{A}\left(0.1 \% \mathrm{TFA} / \mathrm{H}_{2} \mathrm{O}\right)$ and $\mathrm{B}\left(60 \% \mathrm{ACN} / 0.1 \% \mathrm{TFA} / \mathrm{H}_{2} \mathrm{O}\right)$ at a flow rate of $0.4 \mathrm{~mL} / \mathrm{min}$ using a linear gradient of $5-95 \%$ $\mathrm{B}$ in $30 \mathrm{~min}$ and UV detection at $220 \mathrm{~nm}$. The condition used for mass spectrometry measurements was a positive ESI. Peptide sequencing were carried out in an electrospray triplequadrupole Quattro II equipments (Micromass, Manchester, U.K.) by applying the CID-MS/MS method. ${ }^{38)}$ Each sample was analyzed in duplicate.

Bioassays The experiments were carried out with C57BL/6J mice and followed the care and uses of laboratory animals, as well as ethical guidelines for investigations, and were pre-approved by the Animal Care Committee of the Federal University of Sao Paulo. The animals were maintained on standard mouse chow at $21-23^{\circ} \mathrm{C}$ and kept on $12 \mathrm{~h}$ light: $12 \mathrm{~h}$ dark cycle and allowed ad libitum access to food and water. Stomach fundus was isolated from mice, divided in two strips of the longitudinal muscle and mounted into a $7 \mathrm{~mL}$ organ baths (Panlab s.l., Cornella, CA, Spain), containing modified Krebs-Ringer solution: $144 \mathrm{~mm} \mathrm{NaCl}, 5 \mathrm{~mm} \mathrm{KCl}, 1.1 \mathrm{~mm}$ $\mathrm{MgSO}_{4}, 25 \mathrm{~mm} \mathrm{NaHCO}, 1.1 \mathrm{~mm} \mathrm{NaH} \mathrm{PO}_{4}, 1.25 \mathrm{~mm} \mathrm{CaCl}$ and $5.5 \mathrm{~mm}$ glucose) at $37^{\circ} \mathrm{C}(\mathrm{pH} 7.4)$ continuously carboxygenated $\left(95 \% \mathrm{O}_{2} / 5 \% \mathrm{CO}_{2}\right)$. Resting tension was maintained at $0.5 \mathrm{~g}$ and the tissues were left to equilibrate for $90 \mathrm{~min}$, with frequent changing of fresh bathing solution. Following, changes in tension produced by the stimulants were measured with a tension transducer TRI201 (Panlab s.1., Cornella, CA, Spain), through an amplifier Powerlab 4/30 and software Labchart Pro V7 (AD Instruments, Colorado Springs, CO, U.S.A.). Cumulative concentration-response curves were constructed for peptide by applying increasing concentrations $(0.1 \mathrm{nM}$ to $1 \mu \mathrm{M})$ of agonist to determine the apparent affinity of agonists in terms of $\mathrm{p} D_{2}$ (the negative logarithm of the concentration of agonist that produces $50 \%$ of the maximal effect) and the maximal effect $\left(E_{\max }\right)$ was calculated in relation to the effect of $140 \mathrm{~mm}$ of $\mathrm{KCl}$, which was considered $100 \%$. The curvefitting analysis for dose-response curves was performed using 

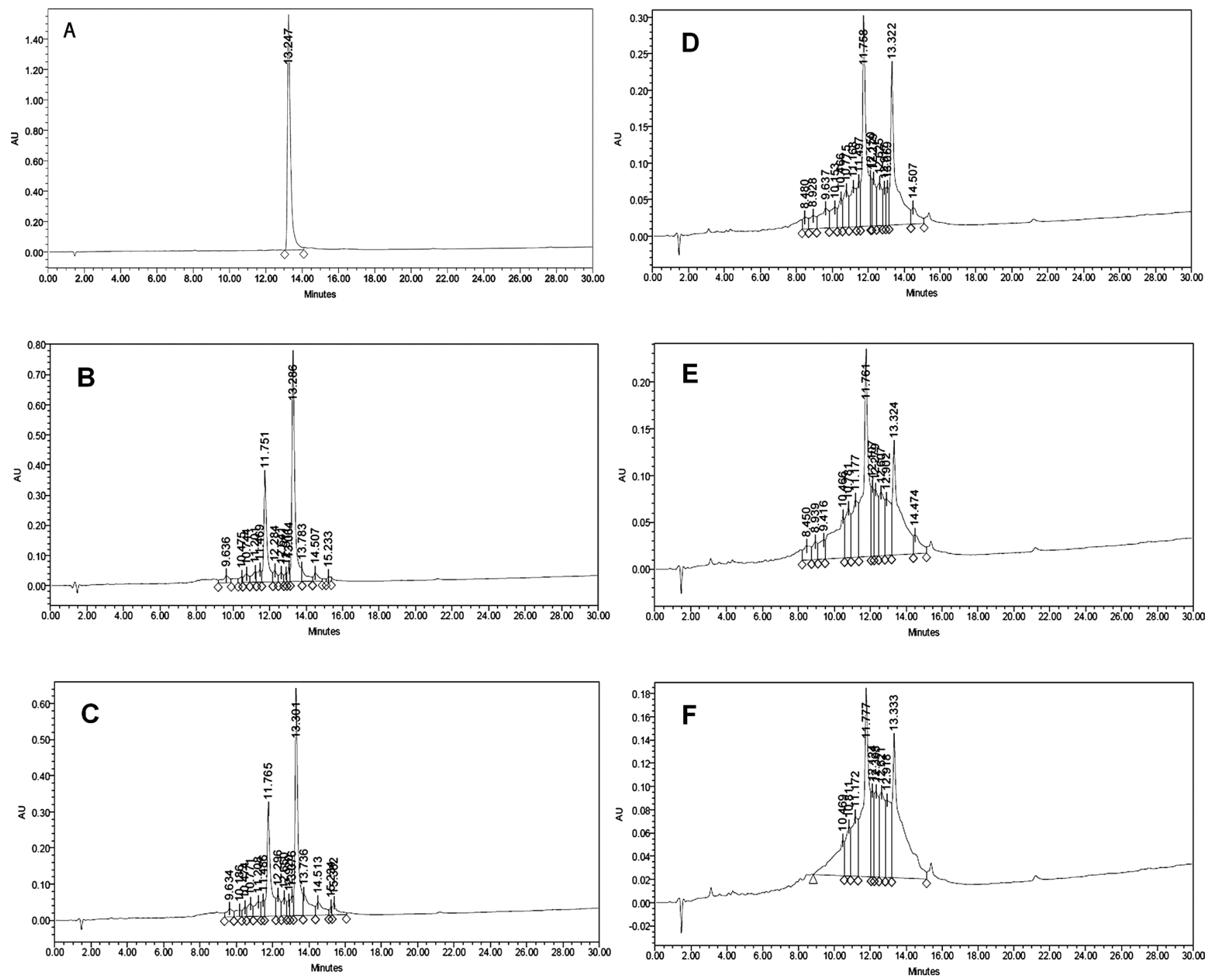

Fig. 1. Chromatogram of $\alpha$-MSH Degradation

HPLC profiles of solutions of non-irradiated $\alpha$-MSH (A) and irradiated with 1 (B), 2 (C), 4 (D), 6 (E) and 8 (F) kGy of gamma radiation doses.

the GraphPad-Prism 3.0 Program (GraphPad Software, San Diego, CA, U.S.A.).

\section{RESULTS AND DISCUSSION}

Details of the synthesis of peptides used in the present work were described in the Method section, including those applied specifically for peptides containing the stable free radical Toac spin probe. Purification procedures were carried out in semipreparative HPLC as early detailed either for obtaining pure peptides fractions before or after irradiation steps.

Gamma Radiation and Comparative $D_{1 / 2}$ Values As previous reports have revealed that peptide degradation occurs with gamma radiation doses of about 1 to $15 \mathrm{kGy}$, at a 3.32 constant dose rate, ${ }^{11,12}$ values within this range was selected for treatment of aqueous peptide solutions $(1 \mathrm{mg} / \mathrm{mL})$, at room temperature. The results of the irradiation of nine peptide sequences described in the Introduction section demonstrated a progressive and nonlinear degradation process for all samples. As examples, the Figs. 1-3 display the HPLC chromatogram profiles with increasing radiation doses observed for $\alpha$-MSH,
SP and $\mathrm{Pro}^{4}-\mathrm{BK}$, respectively.

Comparatively, it is possible to observe that there is a significant difference in terms not only of degradation rate (for instance, $\mathrm{Pro}^{4}$-BK seems to be more stable than $\alpha-\mathrm{MSH}$ and SP) but also in respect to the amount of by-products formation. In contrast to $\mathrm{Pro}^{4}$-BK (Fig. 3), the latter two derivatives (Figs. 1, 2) displayed small amount of by-products but in greater quantity as observed with the areas of their peaks in HPLC chromatograms. Irrespective of the sequence irradiated, it was possible to detect, concomitantly to the disappearance of the native peptide peak, a progressive increase in the amount of unknown aggregated by-products revealed typically a broader peak in the chromatogram. These compounds are possibly the result of radical-radical termination, cross-linking, fragmentation reactions and/or individual changes is some amino acid residues that occurred as a consequence of the generated reactive radical species by gamma ray irradiation procedure. ${ }^{4,42,43)}$ The Fig. 4 displays collectively, the nonlinear degradation profiles found for all peptides studied in the present work.

Aiming at conducting a more in-depth evaluation of the 

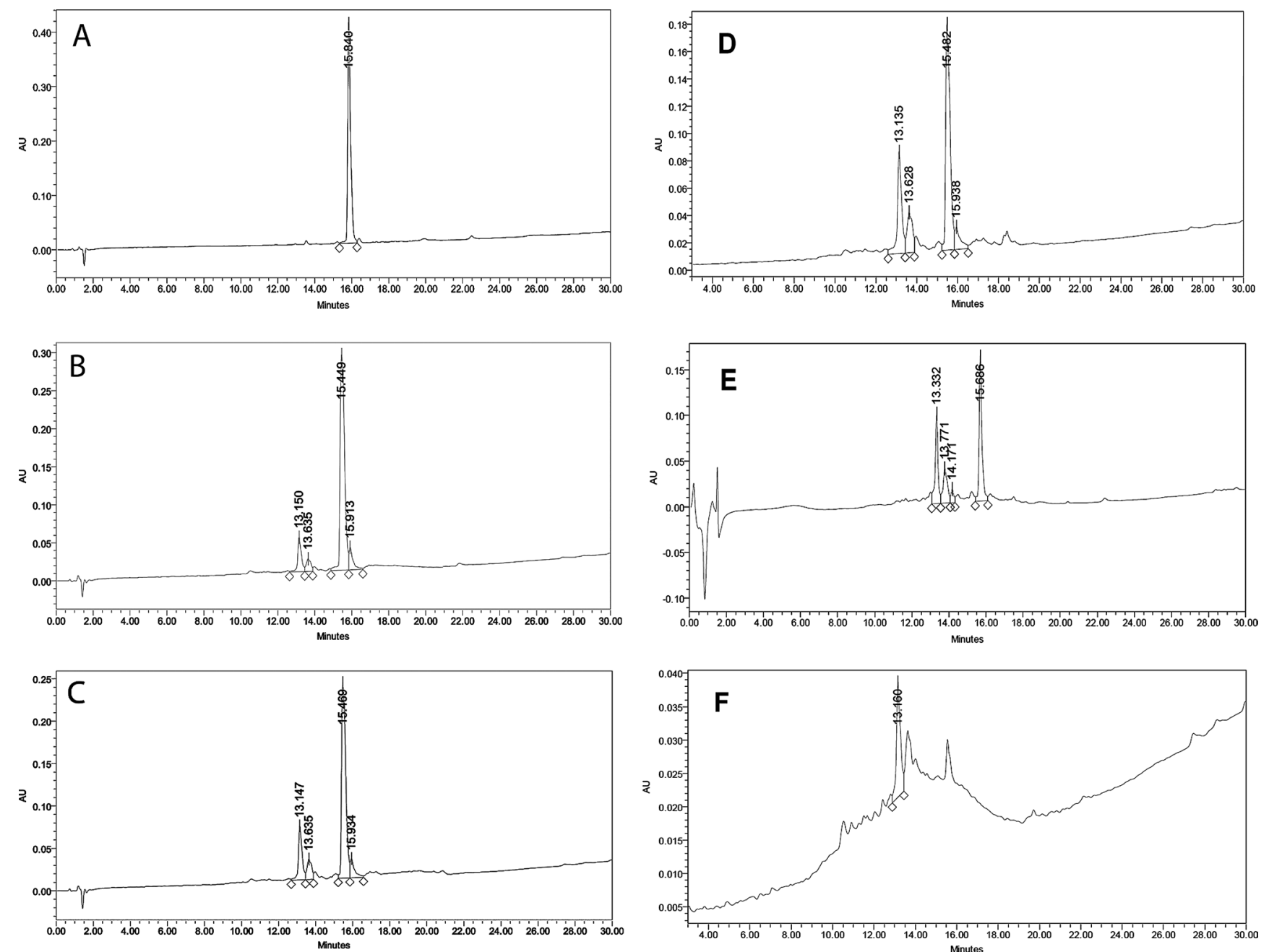

Fig. 2. Chromatogram of SP Degradation

HPLC profiles of solutions of non-irradiated SP (A) and irradiated with 0.3 (B), 0.5 (C), 0.7 (D), 1 (E) and 3 (F) kGy of gamma radiation doses.

peptide degradation process, the $D_{1 / 2}$ values were determined for all peptides. The variation in the quantity of remaining peptide present in the irradiated solution was determined by the peptide peak area (in percentage and taking the nonirradiated sample as control). Table 1 compares the rate of degradation based upon the $D_{1 / 2}$ values which ranged from about 0.5 to $3.5 \mathrm{kGy}$. Interestingly, the most stable class of peptides seems to be related to AngII derivatives that showed $D_{1 / 2}$ values around 3.0-3.5 kGy [Ang-(1-7) and Toac ${ }^{1}-$ AngII]. Moreover, the result with this latter analogue suggested that the stable free radical Toac does not differentiate from other amino acids in terms of stability towards the gamma irradiation.

The other group of peptides characterized by displaying lower structural stability involved the hypotensive peptide BK and its $\mathrm{Pro}^{4}-\mathrm{BK}$, Toac ${ }^{3}-\mathrm{BK}$ and $\mathrm{Toac}^{0}-\mathrm{BK}$ derivatives. The AngII's precursor TDP also pertains to this group which presented $D_{1 / 2}$ values of 1.5 to $2.0 \mathrm{kGy}$. Lastly, the two more labile peptide sequences towards gamma irradiation were $\alpha$-MSH and SP, with $D_{1 / 2}$ values dropping to near $0.5-1.0 \mathrm{kGy}$. Collectively, these findings thus suggested a complex degradation processes involving peptide structures submitted to gamma irradiation procedure and it was not possible to find out specific correlation between the degradation rate values of peptides and their sequences.

Investigation of Peptide Structural Modifications The $\alpha$-MSH, SP and Pro ${ }^{4}$-BK peptides were selected as models for a more complete analysis of chemical modifications that could occur upon the effects of reactive radical species generated in solution by gamma irradiation. Besides the evaluation of the degradation rate revealed above with the $D_{1 / 2}$ parameter, the irradiated solutions of these three peptides were submitted to semi-preparative HPLC purification step in order to obtain purified by-products for further appropriate structural identification through different methodologies.

$\boldsymbol{\alpha}$-MSH (Ac-SYSMEHFRWGKPV-amide) This peptide is produced by pituitary gland of mammals and the epithelium of some vertebrates and seems to be involved in staining of the epidermis, ${ }^{33)}$ obesity $^{44)}$ and other biological functions. ${ }^{45,46)}$ This peptide was also labeled with Toac probe at the N-terminal portion, providing the first fully biologically active peptide analogue in the literature containing this non-natural amino acid-type and paramagnetic molecule. ${ }^{47,48)}$

In terms of gamma irradiation effect, this peptide revealed a pronounced degradation (Fig. 1), with $D_{1 / 2}$ value of only about $1 \mathrm{kGy}$ (Table 1). Its degradation process showed the appearance of a single by-product after gamma irradiation experiment and with retention time around 12 min (Figs. 1B, C) 

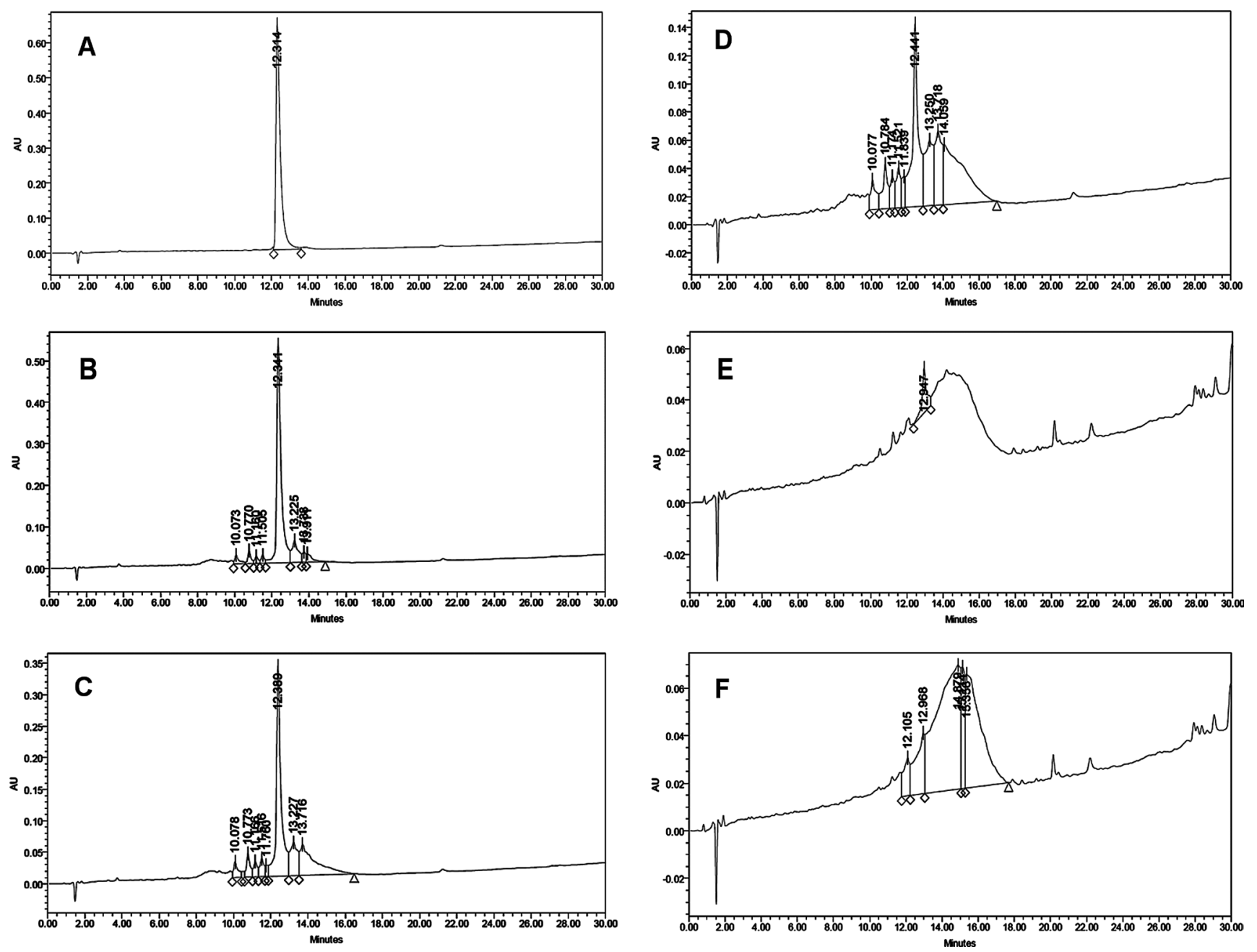

Fig. 3. Chromatogram of Pro ${ }^{4}-\mathrm{BK}$ Degradation

HPLC profiles of solutions of non-irradiated Pro ${ }^{4}$-BK (A) and irradiated with 1 (B), 2 (C), 4 (D), 6 (E) and 8 (F) kGy of gamma radiation doses.

vs 13 min of the native $\alpha$-MSH (identified by molecular weight (MW) of 1665 in LC/ESI-MS spectrum). In these figures, it is also possible to observe that its amount is around $40 \%$ (estimated by the height of HPLC peaks) at 1 or $2 \mathrm{kGy}$ dose in comparison to the original peptide.

To better verify the structure modification occurred with the $\alpha$-MSH generating the single by-product, $25 \mathrm{mg}$ of previously purified $\alpha$-MSH were irradiated in aqueous solution $(1 \mathrm{mg} / \mathrm{mL})$ with $1 \mathrm{kGy}$ dose of gamma radiation. In addition to the recovery of $8.6 \mathrm{mg}$ of native $\alpha-\mathrm{MSH}$, the irradiated solution was next submitted to semi-preparative HPLC step, yielding $3.8 \mathrm{mg}$ of pure analogue above mentioned. The initial characterization of this compound involved the amino acid analysis which indicated a lack of the Met residue in the chromatogram. Next, the electrospray triple quadrupole mass spectrometry through direct infusion method of peptide solution was used and the mass spectrum of isolated analogue is displayed in Fig. 5. As can be seen, there is a peak with $m / z=1680.7$, which corresponds to a molecular ion (Fig. 5A), i.e., $16 \mathrm{Da}$ greater than that of $\alpha$-MSH $(1665 \mathrm{Da})$. Thus, in association with the amino acid analysis, it is possible to infer that this $16-\mathrm{Da}$ increase seems to be due to an oxygen atom addition to the Met residue, yielding $\alpha$-MSH derivative containing the Met sulfoxide $[\operatorname{Met}(\mathrm{O})$ or $\mathrm{M}(\mathrm{O})]$.
The next applied step for examining peptide sequence of the isolated product was the CID-MS/MS which allowed monitoring sequentially the entire fragmentation pattern of the peptide, thus confirming that Met residue was modified in the $\alpha$-MSH. The mass spectrum of this analogue, with this respective prediction of ion fragmentations, is shown in Fig. 5B.

The $m / z=1680.7$ precursor ion was selected to be the most abundant during the fragmentation and a series of type $b$ and $y$ ions ${ }^{49)}$ were used for amino acid sequence deduction of each sample (see Fig. 5B and its corresponding table $5 \mathrm{C}$ of CID-MS/MS data). The presence of $y 7$ ion $(\mathrm{m} / \mathrm{z}=888.5)$, corresponding to the sequence VPKGWRF, $y 10$ ion $(\mathrm{m} / \mathrm{z}=1301.6)$, corresponding to the sequence VPKGWRFHEM(O) and ion $b 11 \quad(m / z=1467.6)$, corresponding to the sequence SYSM(O)EHFRWGK (Fig. 5B) proved that there occurred the Met oxidation residue instead, for instance, of the oxidationsensitive Phe residue also present in the $\alpha$-MSH sequence. These ions can be compared directly to predicted peaks of the $\alpha$-MSH sequence, in which $y 10$ and $b 11$ should be $m / z=1285.6$ and $m / z=1451.6$, respectively (data not shown). Based on these findings, it was possible to conclude that the isolated analogue produced by gamma irradiation has the modification only at the Met residue, yielding the Ac-SYSM(O)EHFRWGKPVamide derivative. 

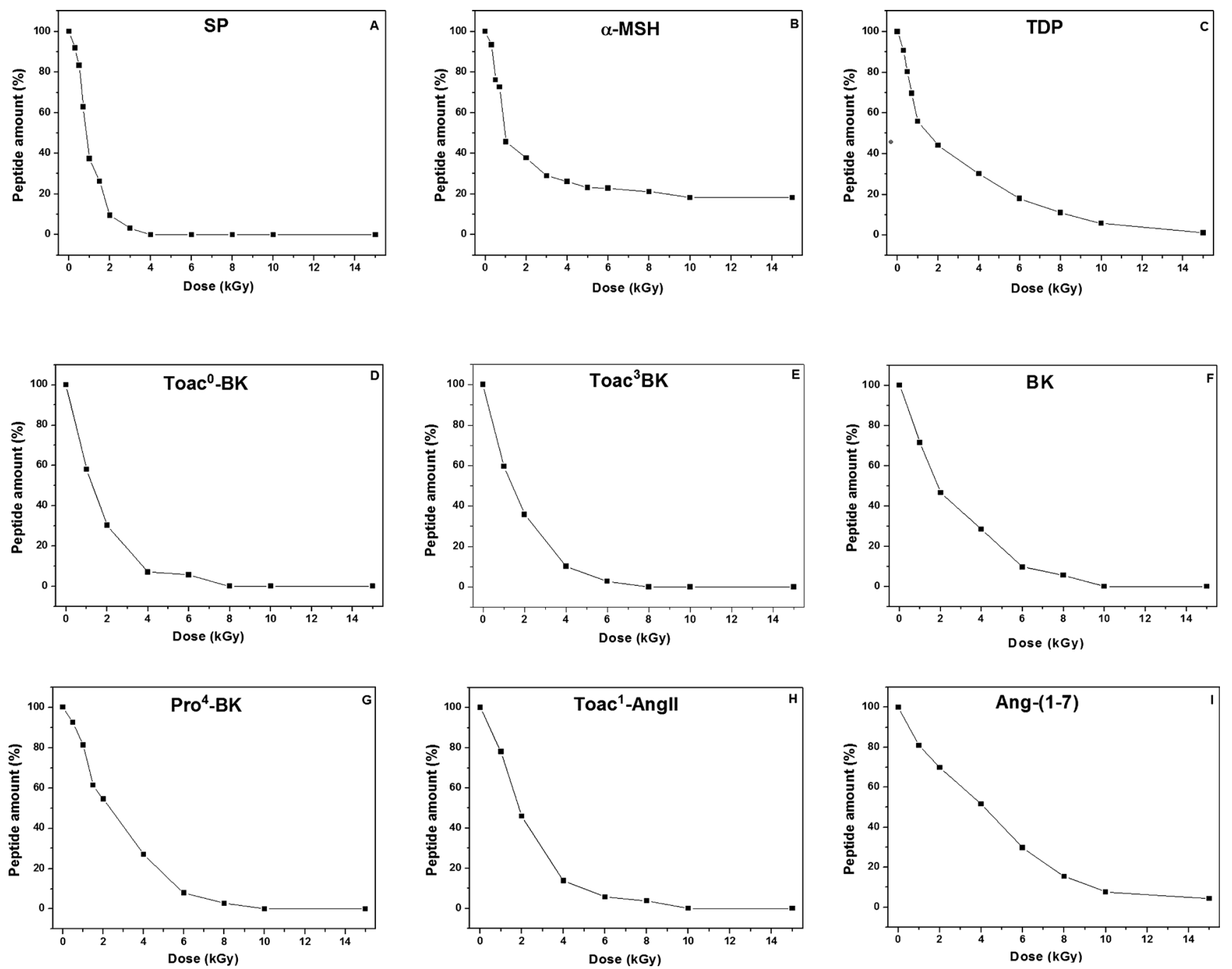

Fig. 4. Degradation Profiles of Peptides

Variation of the amount (\%) of SP (A), $\alpha$-MSH (B), TDP (C), Toac ${ }^{0}-\mathrm{BK}$ (D), Toac ${ }^{3}-\mathrm{BK}(\mathrm{E})$, BK (F), Pro ${ }^{4}-\mathrm{BK}(\mathrm{G})$, Toac - AngII (H) and Ang-(1-7) (I) as a function of the gamma irradiation dose.

Table 1. Half-Life Dose $\left(D_{1 / 2}\right)$ Values of Peptides Submitted to Gamma Ray Irradiation

\begin{tabular}{|c|c|c|c|}
\hline Peptides & Sequence & $D_{1 / 2}$ & MW \\
\hline SP & RPKPQQFFGLM-NH ${ }_{2}$ & 0.5 & 1347 \\
\hline$\alpha$-MSH & Ac-SYSMEHFRWGKPV-NH ${ }_{2}$ & 1.0 & 1665 \\
\hline TDP & DRVYIHPFHLLVYS-OH & 1.5 & 1759 \\
\hline Toac $^{0}-\mathrm{BK}$ & ToacRPPGFSPFR-OH & 1.5 & 1257 \\
\hline Toac $^{3}-$ BK & RPToacGFSPFR-OH & 1.5 & 1161 \\
\hline $\mathrm{BK}^{a)}$ & RPPGFSPFR-OH & 2.0 & 1060 \\
\hline $\mathrm{Pro}^{4}-\mathrm{BK}$ & RPPPFSPFR-OH & 2.0 & 1101 \\
\hline Toac ${ }^{1}$-AngII & ToacRVYIHPF-OH & 3.0 & 1128 \\
\hline Ang-(1-7) & DRVYIHP-OH & 3.5 & 899 \\
\hline
\end{tabular}

a) Nardi et al., 2010.

It is well known that the side chains of the aromatic amino acid and sulfur-containing amino acids are especially vulnerable to attack of reactive radical species. In the latter case, the mechanisms of oxidation are particularly complex and extensive investigation of radiolysis effect of Met seems to indicate primarily the formation of Met-sulfoxide. ${ }^{5,50)}$ Thus, in this context, the present findings are in close accordance with this literature information, although the possible oxidation of other sensitive amino acid residues such as the aromatic Phe or His of the $\alpha$-MSH sequence was not detected. These results were also confirmed by examining only the crude irradiated sample before fractionation of the by-product, using the peptide sequencing property of the CID-MS/MS procedure.

SP (RPKPQQFFGLM-Amide) The SP is a neuronal sensory transmitter associated with pain transmission and also involved in the neuromechanisms of inflammatory chronicity mediated by enzymes such as neutral endopeptidase and angiotensin-converting enzyme. ${ }^{36,51)}$ The Toac-attaching strategy in its sequence has allowed the synthesis of SP analogues with different ability for binding at the cell membrane level. ${ }^{37}$ )

This relevant peptide showed the lowest $D_{1 / 2}$ value $(0.5 \mathrm{kGy})$ amongst the peptides studied in the present work (Fig. 2, Table 1). Following with similar irradiation-purification approach applied for $\alpha$-MSH, $30 \mathrm{mg}(1 \mathrm{mg} / \mathrm{mL})$ of pure SP were irradiated with $0.5 \mathrm{kGy}$ gamma ray dose and HPLC purification of the irradiated solution yielded $2.2 \mathrm{mg}$ of a pure byproduct and $10.2 \mathrm{mg}$ of native peptide. Amino acid analysis of this SP isolated derivative revealed the lack of Met residue in its sequence. 


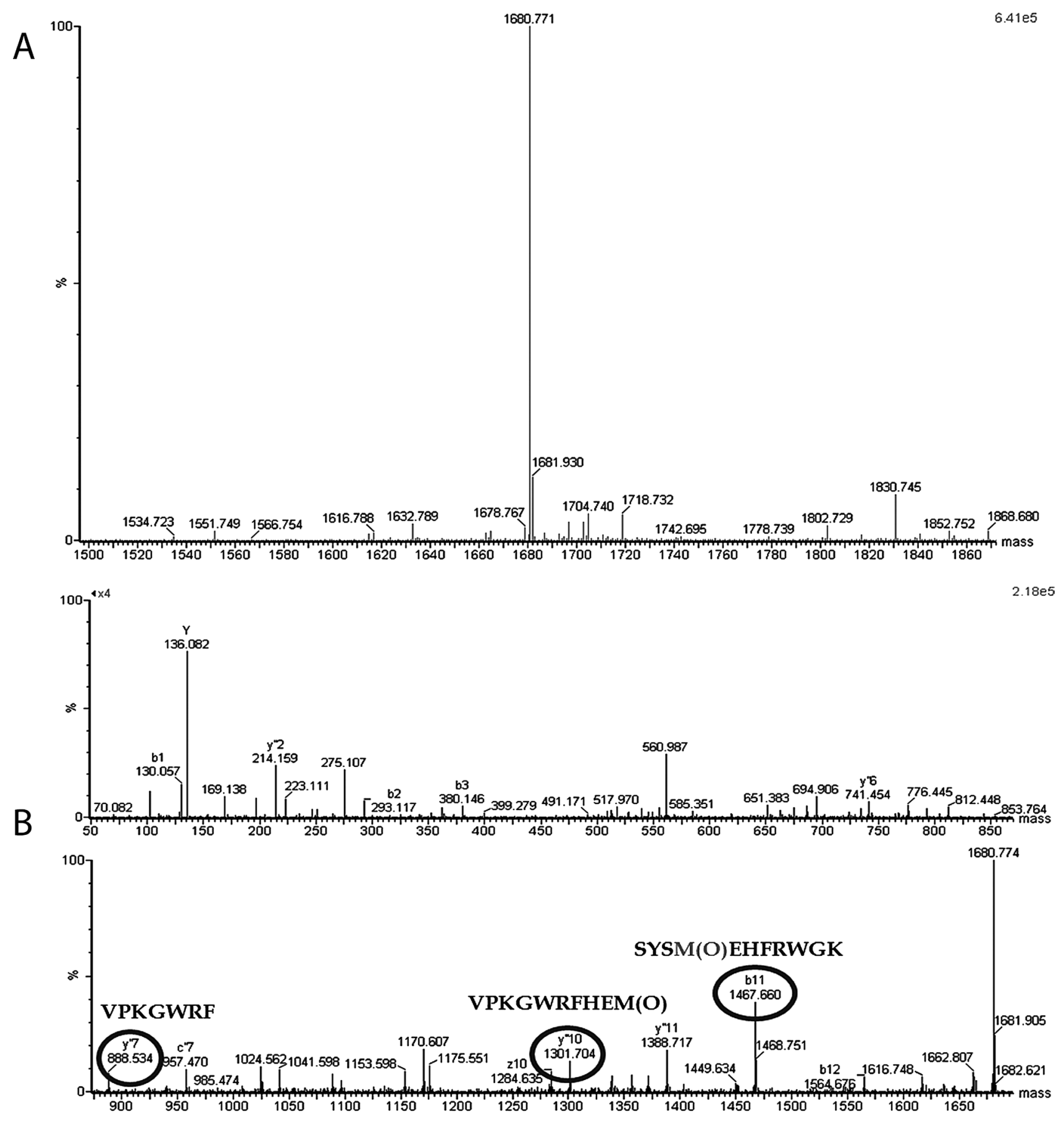

Average Mass $=\mathbf{1 6 8 0 . 9 0 8 0}$, Monoisotopic Mass $=1679.7878$

Residues: 1-13

N-Terminus $=\mathrm{CH} 3 \mathrm{CO}, \mathrm{C}$-Terminus $=\mathrm{NH} 2$

Fragment ions: Monoisotopic/Average (1750) m/z ratios with 1 positive charge(s).

\begin{tabular}{|c|c|c|c|c|c|c|c|c|c|c|c|c|c|}
\hline $\mathbf{a}$ & 102.056 & 265.119 & 352.151 & 499.186 & 628.229 & 765.288 & 912.356 & 1068.457 & 1254.537 & 1311.558 & 1439.653 & 1536.706 & - \\
\hline b & 130.050 & 293.114 & 380.146 & 527.181 & 656.224 & 793.283 & 940.351 & 1096.452 & 1282.531 & 1339.553 & 1467.648 & 1564.701 & - \\
\hline c" & 143.077 & 310.140 & 397.172 & 544.208 & 673.250 & 810.309 & 957.378 & 1113.479 & 1299.558 & 1356.579 & 1484.674 & 1581.327 & - \\
\hline i & 60.045 & 136.076 & 60.045 & 120.048 & 102.056 & 110.072 & 120.081 & 129.114 & 159.092 & 30.034 & 101.108 & 30.066 & 72.081 \\
\hline & 1 & 2 & 3 & 4 & 5 & 6 & 7 & 8 & 9 & 10 & 11 & 12 & 13 \\
\hline & Ser & $\mathbf{T Y Y}$ & Ser & oxdr & Glu & His & Phe & Arg & $\mathbf{T r p}$ & GlY & LYS & Pro & Val \\
\hline & 13 & 12 & 11 & 10 & 9 & 8 & $?$ & 6 & 5 & 4 & 3 & 2 & 1 \\
\hline & - & 1573.732 & 1414.669 & 1323.637 & 1180.602 & 1051.559 & 914.500 & 367.432 & 611.331 & 425.251 & 368.230 & 240.135 & 143.082 \\
\hline$y^{\prime \prime}$ & - & 1551.753 & 1388.690 & 1301.658 & 1154.622 & 1025.580 & 888.521 & 741.452 & 585.351 & 399.272 & 342.250 & 214.156 & 117.103 \\
\hline 7 & - & 1534.727 & 1371.663 & 1284.631 & 1137.596 & 1008.553 & 871.494 & 724.426 & 568.325 & 382.245 & 325.224 & 197.129 & 100.076 \\
\hline
\end{tabular}

Fig. 5. $\alpha$-MSH Structural Determination

Mass spectra of the purified $\alpha$-MSH analogue generated by gamma irradiation (1 kGy) and pointing out the molecular ion MW=1680.771 (A), CID-MS/MS ion fragmentation data (B) and table containing the expected $b$ and $y$ ion fragment series (C). 

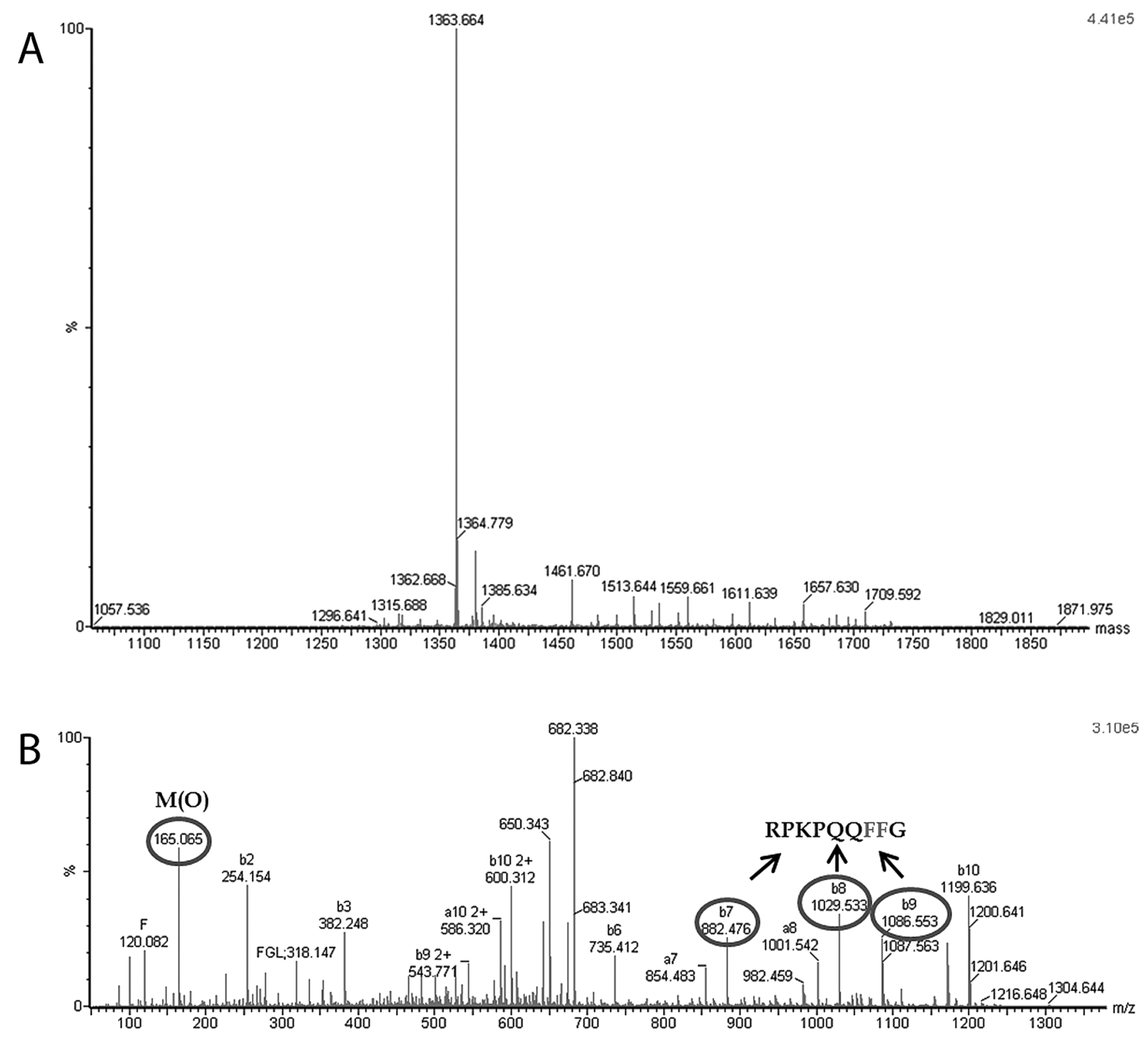

C

Average Mass $=1363.6500$, Monoisotopic Mass $=1362.7230$

Residues: 1-11

$\mathrm{N}$-Terminus $=\mathrm{H}, \mathrm{C}$ - Terminus $=\mathrm{NH} 2$

Fragment ions: Monoisotopic/Average (1750) miz ratios with 1 positive charge(s).

\begin{tabular}{|c|c|c|c|c|c|c|c|c|c|c|c|}
\hline a & 129.114 & 226.167 & 354.262 & 451.314 & 579.373 & 307.432 & 854.500 & 1001.568 & 1058.590 & 1171.674 & - \\
\hline b & 157.109 & 254.162 & 382.257 & 479.309 & 607.368 & 735.427 & 882.495 & 1029.563 & 1086.585 & 1199.669 & - \\
\hline c" & 174.135 & 271.188 & 399.283 & 496.336 & 624.395 & 352.453 & 899.521 & 1046.590 & 1103.611 & 1216.695 & - \\
\hline i & 129.114 & 30.066 & 101.108 & 70.066 & 101.071 & 101.071 & 120.081 & 120.081 & 30.034 & 86.097 & 120.048 \\
\hline & 1 & 2 & 3 & 4 & 5 & 6 & 7 & 8 & 9 & 10 & 11 \\
\hline & frrg & Pro & LYS & Pro & Gln & Gln & Phe & Phe & GlY & Leu & oxds \\
\hline & 11 & 10 & 9 & 8 & 7 & 6 & 5 & 4 & 3 & 2 & 1 \\
\hline$x$ & - & 1233.609 & 1136.556 & 1008.461 & 911.409 & 383.350 & 655.291 & 508.223 & 361.155 & 304.133 & 191.049 \\
\hline$y^{\prime \prime}$ & - & 1207.630 & 1110.577 & 982.482 & 885.429 & 357.371 & 629.312 & 482.244 & 335.175 & 278.154 & 165.070 \\
\hline$z$ & - & 1190.603 & 1093.550 & 965.456 & 868.403 & 340.344 & 612.286 & 465.217 & 318.149 & 261.127 & 148.043 \\
\hline
\end{tabular}

Fig. 6. SP Structural Determination

Mass spectra of purified SP main analogue generated by gamma irradiation ( $0.5 \mathrm{kGy}$ ) pointing out the molecular ion MW=1363.666 (A), CID-MS/MS ion fragmentation data (B) and table containing the expected $b$ and $y$ ion fragment series (C).

By examining the LC/ESI-MS spectrum shown in Fig. 6A, a peak of $m / z=1363$ was observed which corresponds to a molecular ion $16 \mathrm{Da}$ greater than that of SP $(\mathrm{MW}=1347 \mathrm{Da}$, Table 1). This result seems to indicate a Met to $\operatorname{Met}(\mathrm{O})$ transformation induced by the applied irradiation protocol. To better examine this effect, the CID-MS/MS approach was used for the purified SP analogue and the results are displayed in Figs. 6B and C. The $m / z=1363.6$ precursor ion was selected 

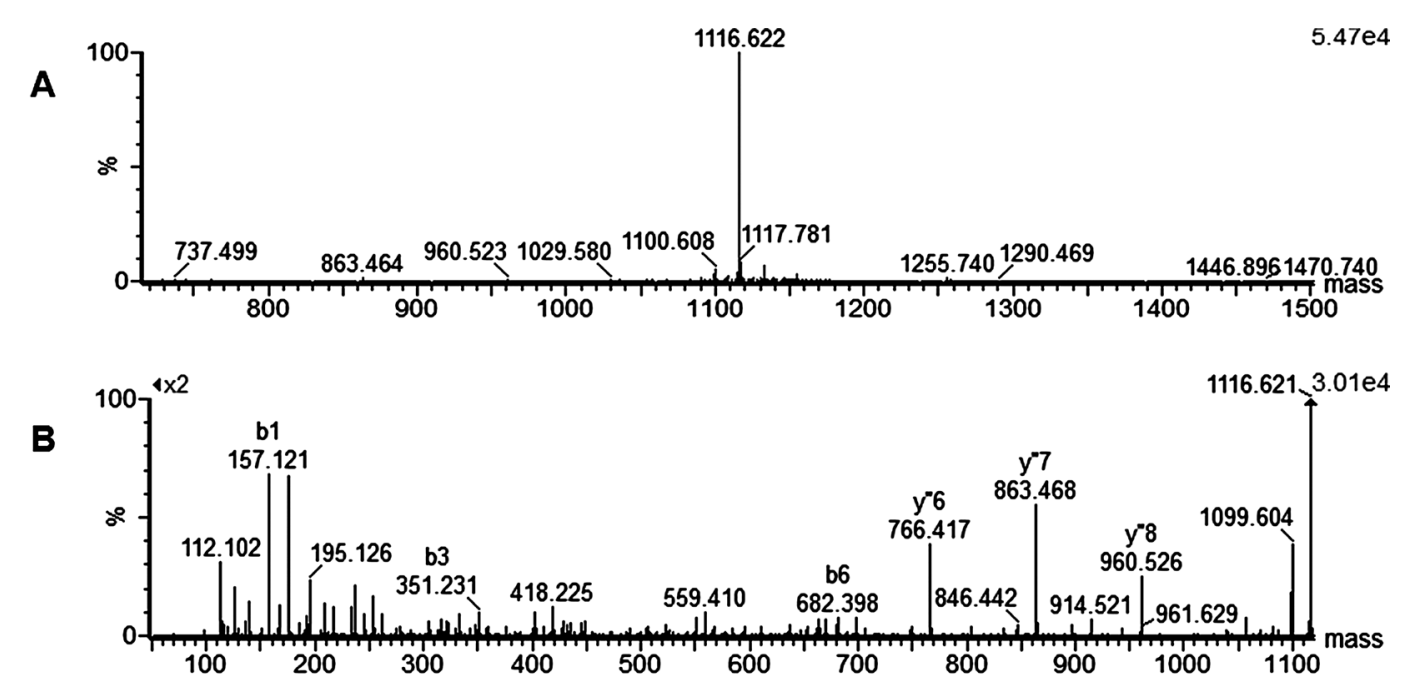

Mass Window $=\mathbf{0 . 8 0}$ amu, Threshold $=1.00 \%$
Average Mass $=\mathbf{1 1 1 6 . 2 8 8 2}$, Monoisotopic Mass $=1115.5875$
Residues: $1-9$
N-Terminus $=\mathrm{H}$, C-Terminus $=$ OH
Fragment ions: Monoisotopic/Average $(1750) \mathrm{m} / \mathrm{z}$ ratios with 1

\begin{tabular}{|c|c|c|c|c|c|c|c|c|c|}
\hline $\mathbf{a}$ & 129.11 & 226.17 & 323.22 & 420.27 & 567.34 & 654.37 & 751.43 & 914.49 & - \\
\hline b & 157.11 & 254.16 & 351.21 & 448.27 & 595.34 & 682.37 & 779.42 & 942.48 & - \\
\hline i & 129.11 & 70.07 & 70.07 & 70.07 & 120.08 & 60.04 & 70.07 & 136.08 & 129.11 \\
\hline & 1 & 2 & 3 & 4 & 5 & 6 & 7 & 8 & 9 \\
\hline & Arg & Pro & Pro & Pro & Phe & Ser & Pro & Tyr & Ars \\
\hline & 9 & 8 & 7 & 6 & 5 & 4 & 3 & 2 & 1 \\
\hline y" & - & 960.49 & 863.44 & 766.39 & 669.34 & 522.27 & 435.24 & 338.18 & 175.12 \\
\hline
\end{tabular}

Fig. 7. Pro ${ }^{4}$-BK Structural Determination

Mass spectra of purified Pro ${ }^{4}$-BK analogue I (similar to II and III) generated by gamma irradiation (2kGy) pointing out the molecular ion MW=1116.6 (A), CID-MS/MS ion fragmentation data (B) and table containing the expected $b$ and $y$ ion fragment series (C).

to be the most abundant during the fragmentation step and the already mentioned series of type $b$ and $y$ ions were used for sequence deduction of this peptide. Initially, it was possible to confirm the presence of $\operatorname{Met}(\mathrm{O})$ in the peptide structure based on the appearance of $y 1$ ion $(m / z=165.06)$ (Fig. 6B).

The Phe hydroxylation to form Tyr residue and also its ortho and meta-isomers has been proposed when this amino acid is submitted to strong electromagnetic radiation. ${ }^{12,52,53)}$ The CID-MS/MS data shown in Fig. 6B disregard this possibility for SP derivative because of the presence of $b 7, b 8$ and b9 ions with $\mathrm{m} / \mathrm{z}=882.4,1029.5$ and 1086.5 , respectively which correspond to RPKPQQF, RPKPQQFF and RPKPQQFFG sequences, respectively. In this context, Chassaing and collaborators $^{54}$ have postulated that the PQQFF segment of the SP molecule is stabilized in $\alpha$-helical-type conformation which would maintain the two adjacent Phe residues in a structure less accessible to reactive hydroxyl radicals.

The analytical HPLC profile of SP shown in Fig. 2C $(0.5 \mathrm{kGy})$ have displayed indeed, other two very small peaks but it was not possible to achieve their successful isolation during the HPLC purification step. Nevertheless, complementary analysis of the CID-MS/MS data of the crude irradiated SP solution did not indicate the presence of any other structurally modified peptide derivative, excepting that containing the $\mathrm{Met}(\mathrm{O})$ residue.

Pro ${ }^{4}$-BK (RPPPFSPFR) Previous gamma irradiation study with $\mathrm{BK}^{12)}$ has surprisingly shown that only the Phe residue located at its position 8 and not 5 was oxidized by reactive hydroxyl group, given rise to $\mathrm{Tyr}^{8}-\mathrm{BK}$ and $m$-Tyr ${ }^{8}-\mathrm{BK}$ analogues. In complement, a similar strong electromagnetic treatment of the potent vasoconstrictor AngII (DRVYIHPF) has also indicated the Phe to Tyr conversion at position 8 of this sequence. ${ }^{11)}$ In common, it can be seen that both oxidized Phe residues of these peptides locate at N-terminal region of the peptide sequences and contain a Pro residue adjacent to their amino-terminus. It is known that the steric hindrance of this cyclic imino acid in cis or trans configuration can affect the reactivity of immediate vicinity amino acids and has been already reported. ${ }^{55)}$ This factor would explain the difference in reactivity between Phe residue when is located at position 8 or 5 of BK sequence.

Thus, in order to focus in this issue, the Pro residue replaced Gly at position 4 of BK sequence (RPPGFSPFR), yielding the Pro ${ }^{4}$-BK analogue and where, the oxidation of $\mathrm{Phe}^{5}$ residue is now expected to occur if the Pro-effect hypothesis above describe is correct. The Fig. 3 displays the HPLC chromatogram of this compound when submitted to increasing gamma irradiation doses. Following the effect observed for all other peptides studied, a nonlinear and increasing degradation of its structure was detected and characterized with the $D_{1 / 2}$ value of about $2 \mathrm{kGy}$.

The HPLC chromatogram revealing the degradation profile of this BK derivative (Fig. 3) also allowed to detect a significant difference with those observed for $\alpha$-MSH and SP (Figs. 1,2 , respectively). This $\mathrm{BK}$ analogue and all other peptides listed in the Table 1 displayed indeed, rather similar profiles 
(data not shown). In these compounds, greater amount of byproducts was formed with the irradiation process but with very low intensities.

Similarly to the carried out with $\alpha-\mathrm{MSH}$ and SP, the $\mathrm{Pro}^{4}$ BK was also submitted to purification of the derivatives generated by the gamma irradiation approach. Fifty milligram of pure sample in aqueous solution were irradiated with $2 \mathrm{kGy}$ radiation dose and three by-products were isolated, with retention times of about 10.1, 10.8 and $11.7 \mathrm{~min}$. Amounts of 1.9, 1.5 and $1.6 \mathrm{mg}$ of the henceforth denoted derivatives I, II and III respectively, were obtained. The amount of recovered native peptide were $14.1 \mathrm{mg}$.

Noteworthy, the initial characterization of these three analogues with amino acid analysis detected a Phe to Tyr transformation but only with one Phe residue. Otherwise, by taking into account the already known retention times of Tyr and their ortho and meta isomers in the chromatogram of the amino acid analyzer, ${ }^{12)}$ is was possible to conclude that the derivatives I, II and III contain $m$-Tyr, $o$-Tyr and Tyr in their composition. Rather similar results were obtained with BK but in this case, only Tyr and $m$-Tyr compounds were identified as the two by-products isolated after gamma irradiation process. ${ }^{12)}$

Corroborating these findings, CID-MS/MS experiments (Fig. 7A) revealed that these three derivatives have the same $\mathrm{m} / \mathrm{z}(1116.6 \mathrm{Da})$, i.e., $16 \mathrm{Da}$ greater than the native peptide $(m / z=1100 \mathrm{Da})$. Thus the point to be addressed argues whether the Phe to Tyr conversion occurred at position 5 or 8 in the Pro $^{4}$-BK. The presence of the $b 6$ ion $(\mathrm{m} / \mathrm{z}=682.4$, corresponding to the sequence RPPPFS) (Fig. 7B) depicted that the $\mathrm{Phe}^{5}$ residue was not affected when the most abundant precursor ion was selected $(m / z=1116.6)$ (Fig. 7A). On the other hand, the presence of the ion $y 8(\mathrm{~m} / \mathrm{z}=960.5$, corresponding to the sequence RYPSFPPP) indicated that the $\mathrm{Phe}^{8}$ residue was oxidized to Tyr (Fig. 7B). In conclusion, the gamma irradiation procedure induced the $\mathrm{Pro}^{4}-\mathrm{BK}$ to generate, in addition to the $\mathrm{Tyr}^{8}$-BK analogue, its $o$ - and $m$-isomers (analogues I-III). In terms of effect of the gamma ray irradiation, these findings rather mimicked those observed for BK as early discussed. ${ }^{12)}$ And finally, it is now possible to infer that the presence of Pro residue adjacent to the $\mathrm{N}$-terminal extremity of Phe is not a prerequisite for oxidation of this aromatic amino acid as early suggested.

These results also led us to argue about the lack of oxidation reaction with the Phe residue present in $\alpha$-MSH and SP sequences. In both cases, this aromatic residue is located internally in their sequences thus suggesting a position- and sequence-dependent effect for the attack of reactive hydroxyl species generated in solution, especially in the case of the Phe amino acid. This effect was not observed for the case of the Met residues present in these peptides which were both easily oxidized.

Biological Assays As the additional target of the present investigation is related to obtain pure peptide derivatives for further structure-function investigations, the $\operatorname{Met}(\mathrm{O})$-containing $\alpha$-MSH or SP are currently been investigated. Structural evaluation will comprise experiments with different spectroscopy such as dichroism circular (CD), fluorescence, etc., and the biological methodologies to be applied will be those already reported in the corresponding published works. ${ }^{37,47)}$

In the case of the $\mathrm{Pro}^{4}-\mathrm{BK}$ derivative, muscle contractile experiments with stomach fundus of mice was already initiated and its dose-response data involving the $\mathrm{p} D_{2}$ and $E_{\max }$ values (see Materials and Methods) were determined for comparison with the native agonist BK. No evidence for partial or even residual biological function was detected for this derivative. The next step will comprise the study of its (I-III) three isolated analogues. The hope is to develop initially a basic structure-function approach with these by-products as already reported for $\mathrm{BK}^{12)}$ In this case, the $\mathrm{Tyr}^{8}$-BK analogue presented greater conformational similarity to the native $\mathrm{BK}$ than the $m$-Tyr ${ }^{8}$-BK analogue (revealed by CD experiments). In close agreement with these findings, the biological experiments revealed that the former derivative presented greater activities (50\% in rat uterus and $10 \%$ in guinea-pig ileum) than the latter (10\% in both smooth muscle preparations).

\section{CONCLUSION}

This report investigated the effect of reactive radical species generated by gamma ray irradiation in solution upon the structures of a set of nine peptide sequences with almost all existing natural amino acids. The range of the irradiation dose ranged from 0.3 to $15 \mathrm{kGy}$ and, regardless of the sequence, this procedure induced a nonlinear and progressive degradation of all peptides which was paralleled by the increased generation of different types of by-products. The introduced $D_{1 / 2}$ parameter which represents the radiation dose necessary for $50 \%$ degradation of initial peptide amount, varied for about 0.5 to $3.5 \mathrm{kGy}$. The degradation data indicated that the most labile class of peptides $\left(D_{1 / 2} c a\right.$. 0.5 to $\left.1.0 \mathrm{kGy}\right)$ was represented by those bearing a Met residue in their sequences (SP and $\alpha$-MSH) followed by those containing the Phe residue. The paramagnetic amino acid-type Toac-containing peptides did not show significant difference in terms of $D_{1 / 2}$ values, thus indicating the absence of a special susceptibility of this unique free radical towards gamma irradiation experiment.

To better examine the chemical modifications induced by the strong electromagnetic irradiation procedure, three peptides-SP, $\alpha$-MSH and $\mathrm{Pro}^{4}$-BK-were selected for purification and further characterization of generated by-products. These structural changes were checked by amino acid analysis, LC/ESI-MS and CID-MS/MS methods. The Met-bearing $\mathrm{SP}$ and $\alpha$-MSH displayed surprisingly only the Met(O) formation, although the oxidation-sensitive Phe residue was also present in their sequences. Otherwise, Pro ${ }^{4}$-BK generated three derivatives under the irradiation experiments, characterized by Phe to Tyr, $m$-Tyr and $o$-Tyr transformation. However, this transformation was position-dependent as only Phe at position 8 in the peptide sequence was not affected.

Taken together, these results demonstrated that the chemical effect of reactive species upon peptide structures is a very complex process, depending on factors such as the amino acid composition, reactive residue position and possibly the conformation acquired by each macromolecule. Needless to stress that much of these findings obtained with the study of small peptides would also be extended to larger molecules such a protein. Finally, the herein applied approach relies also in the hope of generating and isolating uncommon peptide derivatives, not easily obtained by conventional synthesis method, for further structure-function investigations. This target is currently in progress with SP, $\alpha-\mathrm{MSH}$ and $\mathrm{Pro}^{4}-\mathrm{BK}$ 
derivatives.

Acknowledgments Financial support from the Conselho Nacional de Desenvolvimento Científico e Tecnológico (CNPq, National Council for Scientific and Technological Development), the Coordenação de Aperfeiçoamento de Pessoal de Nivel Superior (CAPES, Coordination of the Advancement of Higher Education) and the Fundação de Amparo à Pesquisa do Estado de São Paulo (FAPESP, Foundation for the Support of Research in the State of Sao Paulo) are acknowledged. R.F.F.V. is recipient of Post-Doctoral fellowship from FAPESP.

\section{REFERENCES}

1) Simic MG. DNA markers of oxidative processes in vivo: relevance to carcinogenesis and anticarcinogenesis. Cancer Res., 54 (Suppl.), 1918s-1923s (1994).

2) Selkoe DJ. Cell biology of the amyloid beta-protein precursor and the mechanism of Alzheimer's disease. Annu. Rev. Cell Biol., 10, 373-403 (1994).

3) Opara EC. Role of oxidative stress in the etiology of type 2 diabetes and the effect of antioxidant supplementation on glycemic control. J. Investig. Med., 52 (01-S1), 19-23 (2004).

4) Garrison WM. Reaction-mechanisms in the radiolysis of peptides, polypeptides and proteins. Chem. Rev., 87, 381-398 (1987).

5) Stadtman ER. Oxidation of free amino acids and amino acid residues in proteins by radiolysis and by metal-catalyzed reactions. Annu. Rev. Biochem., 62, 797-821 (1993).

6) Do Nascimento N, Seebart CS, Francis B, Rogero JR, Kaiser II. Influence of ionizing radiation on crotoxin: biochemical and immunological aspects. Toxicon, 34, 123-131 (1996).

7) Hawkins CL, Davies MJ. Generation and propagation of radical reactions on proteins. Biochim. Biophys. Acta, 1504, 196-219 (2001).

8) Stadtman ER, Levine RL. Free radical-mediated oxidation of free amino acids and amino acid residues in proteins. Amino Acids, 25, 207-218 (2003)

9) Von Sonntag C. The basis of radiation biology. 3rd ed., Taylor \& Francis, London, 1987.

10) Houée-Levin C, Sicard-Roselli C. Radiation chemistry: present status and future trends. (Jonah CD, Rao BSM eds.) Elsevier Science B.V., Amsterdam, pp. 1-755 (2001).

11) Nardi DT, Casare MS, Teixeira LG, Nascimento N, Nakaie CR. Effect of gamma radiation on the structural and biological properties of angiotensin II. Int. J. Radiat. Biol., 84, 937-944 (2008).

12) Nardi DT, Rosa JC, Jubilut GN, Miranda A, Nascimento N, Nakaie CR. Gamma ray irradiation of the vasoactive peptide bradykinin reveals a residue- and position-dependent structural modification. Int. J. Pept. Res. Ther., 16, 71-78 (2010).

13) Catt KJ, Sandberg K, Balla T. Cellular and molecular biology of the renin-angiotensin system. (Raizada MK, Phillips MI, Summers C eds.) CRC Press, Boca Raton, pp. 307-356 (1993).

14) Timmermans PB, Wong PC, Chiu AT, Herblin WF, Benfield P, Carini DJ, Lee RJ, Wexler RR, Saye JA, Smith RD. Angiotensin II receptors and angiotensin II receptor antagonists. Pharmacol. Rev., 45, 205-251 (1993).

15) Oliveira L, Costa-Neto CM, Nakaie CR, Schreier S, Shimuta SI, Paiva AC. The angiotensin II AT1 receptor structure-activity correlations in the light of rhodopsin structure. Physiol. Rev., 87, 565-592 (2007).

16) Regoli D, Barabé J. Pharmacology of bradykinin and related kinins. Pharmacol. Rev., 32, 1-46 (1980).

17) Bhoola KD, Figueroa CD, Worthy K. Bioregulation of kinins: kallikreins, kininogens, and kininases. Pharmacol. Rev., 44, 1-80 (1992).

18) Nakaie CR, Goissis G, Schreier S, Paiva ACM. pH-Dependence of electron-paramagnetic-resonance spectra of nitroxides containing ionizable groups. Braz. J. Med. Biol. Res., 14, 173-180 (1981).

19) Marchetto R, Schreier S, Nakaie CR. A novel spin-labeled amino-acid derivative for use in peptide-synthesis-(9-fluorenylmethyloxycarbonyl)-2,2,6,6-tetramethylpiperidine- $N$-oxyl-4amino-4-carboxylic acid. J. Am. Chem. Soc., 115, 11042-11043 (1993).

20) Nakaie CR, Silva EG, Cilli EM, Marchetto R, Schreier S, Paiva TB, Paiva AC. Synthesis and pharmacological properties of Toac-labeled angiotensin and bradykinin analogs. Peptides, 23, 65-70 (2002).

21) Schreier S, Barbosa SR, Casallanovo F, Vieira RF, Cilli EM, Paiva AC, Nakaie CR. Conformational basis for the biological activity of Toac-labeled angiotensin II and bradykinin: electron paramagnetic resonance, circular dichroism, and fluorescence studies. Biopolymers, 74, 389-402 (2004).

22) Vieira RFF, Casallanovo F, Marín N, Paiva ACM, Schreier S, Nakaie CR. Conformational properties of angiotensin II and its active and inactive Toac-labeled analogs in the presence of micelles. Electron paramagnetic resonance, fluorescence, and circular dichroism studies. Biopolymers, 92, 525-537 (2009).

23) Toniolo C, Valente E, Formaggio F, Crisma M, Pilloni G, Corvaja C, Toffoletti A, Martinez GV, Hanson MP, Millhauser GL, George C, Flippen-Anderson JL. Synthesis and conformational studies of peptides containing Toac, a spin-labelled C alpha, alpha-disubstituted glycine. J. Pept. Sci., 1, 45-57 (1995).

24) Smythe ML, Nakaie CR, Marshall GR. Alpha-helical versus 3(10)-helical conformation of alanine-based peptides in aqueoussolution-an electron-spin-resonance investigation. J. Am. Chem. Soc., 117, 10555-10562 (1995).

25) Karim CB, Kirby TL, Zhang Z, Nesmelov Y, Thomas DD. Phospholamban structural dynamics in lipid bilayers probed by a spin label rigidly coupled to the peptide backbone. Proc. Natl. Acad. Sci. U.S.A., 101, 14437-14442 (2004).

26) Marsh D, Jost M, Peggion C, Toniolo C. Toac spin labels in the backbone of alamethicin: EPR studies in lipid membranes. Biophys. J., 92, 473-481 (2007).

27) Van Eps N, Anderson LL, Kisselev OG, Baranski TJ, Hubbell WL, Marshall GR. Electron paramagnetic resonance studies of functionally active, nitroxide spin-labeled peptide analogues of the Cterminus of a G-protein alpha subunit. Biochemistry, 49, 6877-6886 (2010).

28) Cilli EM, Marchetto R, Schreier S, Nakaie CR. Correlation between the mobility of spin-labeled peptide chains and resin solvation: an approach to optimize the synthesis of aggregating sequences. $J$. Org. Chem., 64, 9118-9123 (1999).

29) Oliveira E, Cilli EM, Miranda A, Jubilut GN, Albericio F, Andreu D, Paiva ACM, Schreier S, Tominaga M, Nakaie CR. Monitoring the chemical assembly of a transmembrane bradykinin receptor fragment: correlation between resin solvation, peptide chain mobility, and rate of coupling. Eur. J. Org. Chem., 2002, 3686-3694 (2002).

30) Marchetto R, Cilli EM, Jubilut GN, Schreier S, Nakaie CR. Determination of site-site distance and site concentration within polymer beads: a combined swelling-electron paramagnetic resonance study. J. Org. Chem., 70, 4561-4568 (2005).

31) Zhang ZW, Remmer HA, Thomas DD, Karim CB. Backbone dynamics determined by electron paramagnetic resonance to optimize solid-phase peptide synthesis of Toac-labeled phospholamban. Biopolymers, 88, 29-35 (2007).

32) Schreier S, Bozelli JC Jr, Marín N, Vieira RF, Nakaie CR. The spin label amino acid Toac and its uses in studies of peptides: chemical, physicochemical, spectroscopic, and conformational aspects. Biophysical Reviews, 4, 45-66 (2012).

33) Vaudry H, Eberle A. The melanotropic peptides. 1st ed., New York Academy of Sciences, New York (1993).

34) Abdel-Malek Z, Swope VB, Suzuki I, Akcali C, Harriger MD, 
Boyce ST, Urabe K, Hearing VJ. Mitogenic and melanogenic stimulation of normal human melanocytes by melanotropic peptides. Proc. Natl. Acad. Sci. U.S.A., 92, 1789-1793 (1995).

35) Maggi CA. The mammalian tachykinin receptors. Gen. Pharmacol., 26, 911-944 (1995)

36) Maggi CA, Schwartz TW. The dual nature of the tachykinin NK1 receptor. Trends Pharmacol. Sci., 18, 351-355 (1997).

37) Shafer AM, Nakaie CR, Deupi X, Bennett VJ, Voss JC. Characterization of a conformationally sensitive Toac spin-labeled substance P. Peptides, 29, 1919-1929 (2008).

38) Johnstone RAW, Rose ME. Mass spectrometry for chemists and biochemists. 2nd ed., Cambridge University Press, Cambridge (1996).

39) Barany G, Merrifield RB. The peptides: analysis, synthesis and biology. 1st ed., Academic Press, New York (1980).

40) Fields GB, Noble RL. Solid phase peptide synthesis utilizing 9-fluorenylmethoxycarbonyl amino acids. Int. J. Pept. Protein Res., 35, 161-214 (1990).

41) Kates SA, Albericio F. Solid-phase synthesis: a practical guide. Ilustrated ed., Marcel Dekker, New York (2000).

42) Lee Y, Song KB. Effect of gamma-irradiation on the molecular properties of myoglobin. J. Biochem. Mol. Biol., 35, 590-594 (2002).

43) Gaber MH. Effect of $\gamma$-irradiation on the molecular properties of bovine serum albumin. J. Biosci. Bioeng., 100, 203-206 (2005).

44) Fan W, Boston BA, Kesterson RA, Hruby VJ, Cone RD. Role of melanocortinergic neurons in feeding and the agouti obesity syndrome. Nature, 385, 165-168 (1997).

45) Castrucci AM, Lebl M, Hruby VJ, Matsunaga TO, Hadley ME. Melanin concentrating hormone. III. Melanin concentrating hormone (MCH): the message sequence. Life Sci., 45, 1141-1148 (1989).

46) Castrucci AM, Visconti MA, Matsunaga TO, Hadley ME, Hruby VJ. Enzymological studies of melanin concentrating hormone
$(\mathrm{MCH})$ and related analogues. Comp. Biochem. Physiol. B, 103, 317-320 (1992)

47) Barbosa SR, Cilli EM, Lamy-Freund MT, Castrucci AM, Nakaie CR. First synthesis of a fully active spin-labeled peptide hormone. FEBS Lett., 446, 45-48 (1999).

48) Nakaie CR, Barbosa SR, Vieira RF, Fernandez RM, Cilli EM, Castrucci AM, Visconti MA, Ito AS, Lamy-Freund MT. Comparative EPR and fluorescence conformational studies of fully active spinlabeled melanotropic peptides. FEBS Lett., 497, 103-107 (2001).

49) Roepstorff P, Fohlman J. Proposal for a common nomenclature for sequence ions in mass spectra of peptides. Biomed. Mass Spectrom., 11, 601 (1984).

50) Xu GZ, Chance MR. Radiolytic modification of sulfur-containing amino acid residues in model peptides: fundamental studies for protein footprinting. Anal. Chem., 77, 2437-2449 (2005).

51) Harrison S, Geppetti P. Substance P. Int. J. Biochem. Cell Biol., 33, 555-576 (2001).

52) Biondi R, Ambrosio G, Liebgott T, Cardounel AJ, Bettini M, Tritto I, Zweier JL. Hydroxylation of D-phenylalanine as a novel approach to detect hydroxyl radicals: application to cardiac pathophysiology. Cardiovasc. Res., 71, 322-330 (2006).

53) Miyahara M, Ito H, Nagasawa T, Kamimura T, Saito A, Kariya M, Izumi K, Kitamura M, Toyoda M, Saito Y. Determination of $o$ tyrosine production in aqueous solutions of phenylalanine irradiated with gamma ray, using high performance liquid chromatography with automated pre-column derivatization and LASER fluorometric detection. J. Health Sci., 46, 192-199 (2000).

54) Chassaing G, Convert O, Lavielle S. Preferential conformation of substance P in solution. Eur. J. Biochem., 154, 77-85 (1986).

55) Pullman B, Pullman A. Molecular orbital calculations on the conformation of amino acid residues of proteins. Adv. Protein Chem., 28, 347-526 (1974). 